\title{
SOIL ANALYSIS, SPECIES COMPOSITION AND CARBON DYNAMICS OF ABIES PINDROW FOREST OF DIR KOHISTAN, PAKISTAN
}

\author{
UDDIN, R. $.^{1,3^{*}}-$ ANSARI, L. ${ }^{1}-$ AHMAD, A. ${ }^{2,3}-$ ULlAH, S. ${ }^{3}-$ MUNIR, M. ${ }^{4}-$ SHER, K. ${ }^{5}$ \\ ${ }^{I}$ Department of Forestry and Range Management, Pir Mahir Ali Sha Arid Agriculture \\ University Rawalpindi 46000, Pakistan \\ ${ }^{2}$ Department of Forest Sciences, Beijing Forestry University \\ Beijing 100083, China \\ ${ }^{3}$ Department of Forestry, Shaheed Benazir Bhutto University \\ Sheringal Dir Upper 18000, Pakistan \\ ${ }^{4}$ Department of Botany, University of Veterinary and Animal Sciences \\ Ravi Campus, Pattoki, Pakistan \\ ${ }^{5}$ Department of Botany, Shaheed Benazir Bhutto University \\ Sheringal Dir Upper 18000, Pakistan \\ *Corresponding author \\ e-mail: rahman0944@gmail.com \\ (Received 22 $2^{\text {nd }}$ Jan 2019; accepted $8^{\text {th }}$ Mar 2019)
}

\begin{abstract}
This study highlighted the structure, species composition and biomass carbon stock in the Abies Pindrow dominant community in Dir Kohistan, temperate region of Pakistan. The results showed that stem density varied between $3 \mathrm{ha}^{-1}$ in Acer ceasium to $273 \mathrm{ha}^{-1}$ in Abies pindrow, with a total stand density of 350 trees $\mathrm{ha}^{-1}$. The importance value index (IVI) varied between 2.27 (Acer ceasium) and 62.22 (Abies pindrow). The mean basal area was recorded at $132.15 \mathrm{~m}^{2} \mathrm{ha}^{-1}$. The average stem volume was measured at $120 \mathrm{~m}^{3} \mathrm{ha}^{-1}$. The mean stem and total tree biomass carbon was 639 and $967 \mathrm{t} \mathrm{ha}^{-1}$ respectively. Similarly, the understory vegetation and litter, dead wood and cone biomass carbon was found $1.43 \mathrm{t} \mathrm{ha}^{-1}$ and $12.02 \mathrm{t} \mathrm{ha}^{-1}$ respectively. Soil carbon $(0-30 \mathrm{~cm})$ was calculated by using Walkey-Black methods multiplied by mean soil bulk density measurements. The average soil organic carbon was calculated $70.75 \mathrm{t} \mathrm{ha}^{-1}$. The Total average carbon stock of the community was calculated at $568.63 \mathrm{t} \mathrm{ha}^{-1}$. These results provide the evidence that, Abies Pindrow dominant community has a greater potential of sequestering carbon. Upon proper carbon management the ecosystem might be included in the carbon trading of Kyoto protocol.
\end{abstract}

Keywords: soil, temperate region, structural attributes, growing stock, biomass, carbon, Kumrat Valley

\section{Introduction}

Forests sequester and accumulate more carbon than any other terrestrial ecosystem and are a significant natural 'brake' on climate change (Pan et al., 2011; Espírito-Santo et al., 2014; Manan et al., 2018). Forest biomass contained a significant amount of carbon and can accumulate continuous carbon through their life spin (IPCC, 2006; Ahmad et al., 2014, 2015). Various anthropogenic activities e.g. industrialization, deforestation, forest degradation and burning of fossil fuel, has caused an increase in the level of carbon in the atmosphere and disrupted the global carbon cycle (Sharma and Rai, 2007; Ahmad et al., 2014; Manan et al., 2018). However, nature has its own mechanism of sequestering and storing the carbon in its "reservoirs" or "sinks". The removal of carbon for decreasing the $\mathrm{CO}_{2}$ level is need of the time (Wani et al., 2014, 2016). Forest plays an important role in 
the global carbon cycle as carbon sinks of the terrestrial ecosystem (Coulston et al., 2015; Calfapitera et al., 2015). Forest contained about 4 billion ha of the globe with $861 \pm 66 \mathrm{Pg}$ stock carbon (Wani et al., 2014; FAO, 2015).

The Intergovernmental Panel on Climate Change (IPCC) identified five carbon pools of the forest ecosystem, namely the above-ground biomass, below-ground biomass, litter, woody debris and soil organic matter (Nizami, 2012). Among all the carbon pools, the above-ground biomass constitutes the major portion of the carbon pool (Ahmad et al., 2014). Estimating the amount of forest biomass is very crucial for monitoring and estimating the amount of carbon that is lost or emitted, as well the forest's potential to sequester and store carbon (Ahmad et al., 2018; Manan et al., 2018; Saeed et al., 2019). The IPCC and the Kyoto protocol (KP) identified forest as one of the important tool for the mitigating climate change through managing forest carbon for climate change strategy (Hosonuma et al., 2012). Concerns regarding the climate change mitigation, the international community stresses on the national and regional monitoring of forest carbon under the IPCC proposed guidelines (Böttcher et al., 2008).

Pakistan, being a member, to the IPPC and KP, the measurement of periodic and annual budgeting of the stored carbon in their forest is their obligation. In Pakistan various researcher outline the carbon stock of different forest like in temperate region (Ahmad et al., 2014; Ahmad et al., 2015; Ahmad and Nizami, 2015; Manan et al., 2018; Ahmad et al., 2018), in subtropical region (Nizami, 2012; Manan et al., 2018; Amir et al., 2018) and in planted forest. However, the carbon stock potential as well the species composition of the dominant Abies Pindrow community is not worked out yet. Looking into consideration this study was designed with the objectives to figure out the soil analysis, forest structure, species composition and biomass carbon of the Abies pindrow forest of Dir Kohistan, Pakistan.

\section{Materials and methods}

\section{Study area and research design}

Dir Kohistan is located to the North West side of Khyber Pakhtunkhwa province Pakistan. Geographically Dir Kohistan is mountainous with elevation ranges from 2000 to $6000 \mathrm{~m}$ (Ahmad et al., 2018). The Abies pindrow community occurred with in elevation range of 2500 to $3000 \mathrm{~m}$ along with latitude $35^{\circ} 34^{\prime}$ to $35^{\circ} 43^{\prime}$ and longitude $72^{\circ} 10^{\prime}$ to $72^{\circ} 16^{\prime}$. The mean annual precipitation in area ranges from 1000 to $1500 \mathrm{~mm}$, while the mean temperature ranges from 0.6 to $25^{\circ} \mathrm{C}$ (Ahmad and Nizami, 2015). Geologically most of the rocks are diorites, nitrites, and schist is the principle types of rocks. The underground rocks are mostly quartzite, schist, shale, slate, and granites. Soil is rich in organic matters and acidic in nature (Ahmad and Nizami 2015; Ahmad et al., 2018). For the related data collection, 14 sample plots, each of size 0.1 ha were laid out randomly in the forest (Table Al in the Appendix). The species composition and their related attributes, the growing stock, and biomass carbon in the respective pools were assessed (Fig. 1).

\section{Species composition and related attributes}

The species composition and their related attributed like stem density, relative density, basal area, relative basal area, frequency, relative frequency and importance value index were measured using Equations 1-6 given below. 


$$
\begin{aligned}
& \text { Density }(D)=\frac{\text { Total number of individual of a species in all the sample plots }}{\text { Total number of sample plots taken }} \\
& \text { Relativedensity (D3) }=\frac{\text { Total No,individual of a species in all quadrates }}{\text { Total No.of individuals of all species in all quadrates }} \times 100 \text { (Eq.2) }
\end{aligned}
$$

$$
\begin{aligned}
& \text { Average cover per species, }(\mathbf{C})=\frac{\text { Total cover }(\text { square feet }) \text { of a species }}{\text { Number of plants of a species }} \\
& \text { Relative Cover of Species }(\mathbf{C} 3)=\frac{\text { TotalCoverSqftofallPlantsofallspp }}{\text { TotalCoverSqftofallPlantsofallSpecies }} \\
& \text { Frequency }(\mathbf{F})=\frac{\text { Number of quadrats of occurrence of a species }}{\text { Total number of quadrats used by sampling }} \times 100
\end{aligned}
$$

$$
\text { RelativeFrequency }(\text { F3 })=\frac{\text { Frequency of a species }}{\text { Total frequency of all species }} \times 100
$$

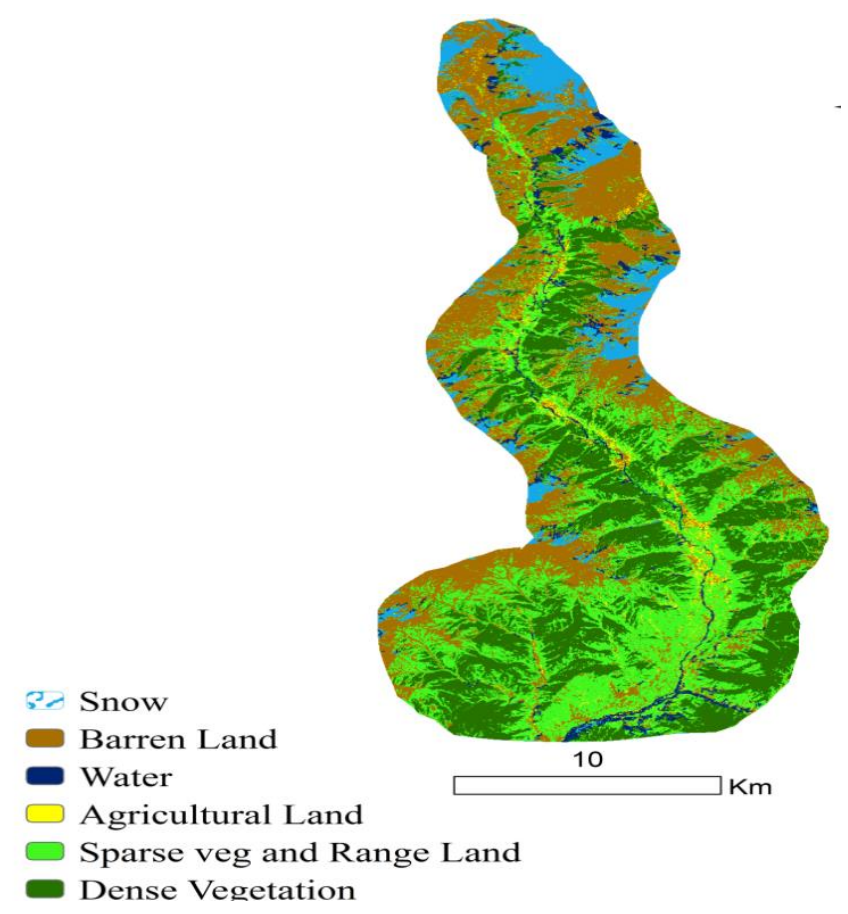

Figure 1. Study area

\section{Importance value index (IVI)}

In mixed forest, data of density, cover and frequency of a species do not give a clear data about the main species. It was estimated by adding the value of relative cover, relative density, and relative frequency and to dividing it by 3 given the importance value index (IVI) of the species. IVI for a forest stand were calculated as the total of the relative density, relative frequency and relative cover (Curtis, 1959).

$$
\text { I. V.I }=\frac{\mathrm{D} 3+\mathrm{C} 3+\mathrm{F} 3}{3}
$$




\section{Biomass carbon estimation}

For upper storey vegetation biomass carbon, in each plot diameter and tree height was measured. The stem volume was measured from the relationship of diameter $(\mathrm{cm})$ and height $(\mathrm{m})$ following formula:

$$
\text { Tree volume }\left(\mathrm{m}^{3}\right)=\pi / 4 \mathrm{~d}^{2} \times \mathrm{h} \times \mathrm{FF}
$$

Stem biomass $(\mathrm{kg})$ was calculated from the relationship of stem volume $\left(\mathrm{m}^{3}\right)$ and basic wood density $\left(\mathrm{Kg} / \mathrm{m}^{3}\right)$. Basic wood density was sourced from available literature (Haripriya, 2000; Ahmad et al., 2014; Manan et al., 2018,). The following formula was used to estimate stem biomass:

$$
\text { Stem biomass }(\mathrm{kg})=\text { Stem volume }\left(\mathrm{m}^{3}\right) \times \text { Wood density }\left(\mathrm{Kg} / \mathrm{m}^{3}\right)
$$

To estimate total biomass, biomass expansion factor was used. The BEF ratio of 1.51 for conifers and 1.55 for broad leaved was used to find out total biomass of a tree (Haripriya, 2000; Ahmad et al.,2018; Manan et al., 2018).

$$
\text { Total biomass }(\mathrm{Kg})=\text { Stem biomass }(\mathrm{Kg}) \times \mathrm{BEF}
$$

For the measurement of understory vegetation, dead wood, cone, and litter biomass carbon, sub plots each of $1 \mathrm{~m}^{2}$ size were laid out. From the each sub plot, the understory vegetation was harvested destructively and dead wood, cone and litter were collected and their fresh weight was measured. The collected samples were oven dried for $48 \mathrm{~h}$ at $72{ }^{\circ} \mathrm{C}$ and their dry weight was taken as their biomass (Ahmad and Nizami, 2015; Ahmad et al., 2018; Manan et al., 2018).

The carbon values were assessed from the biomass of the respective pools. The conversion factor of 0.5 was used to convert biomass into carbon that has been used widely around the Globe (Brown and Lugo, 1982; Malhi et al., 2004; Nizami, 2012; Ahmad et al., 2014; Amir et al., 2018; Saeed et al., 2019). For soil carbon assessment, soil samples were collected from each plot at the depth of $30 \mathrm{~cm}$. The soil organic carbon was measured following (Walkely, 1934). The soil carbon in $\mathrm{t} \mathrm{ha}^{-1}$ was assessed from the soil bulk density, depth increment and soil organic carbon following (Ahmad and Nizami, 2015; Saeed et al., 2018; Ahmad et al., 2018).

\section{Results and discussion}

\section{Species composition and growing stock}

The results regarding the species composition and related attributed are given in Table 1. The results clearly figure out that Abies pindrow is the dominant tree species with the maximum species compositional attributes while the minimum values for these attributes were recorded for Acer cesium. Over all the results showed that the stem density varied between $3 \mathrm{ha}^{-1}$ (Acer caesium) and $276 \mathrm{ha}^{-1}$ (Abies pindrow) with a total stem density of 350 trees ha ${ }^{-1}$. The results of frequency in Table 1 explained that along with Abies pindrow, Taxus baccata and Picea smithiana were found throughout the community. Regarding the growing stock (volume $\mathrm{m}^{3} \mathrm{ha}^{-1}$ ) details are given in Table 2 . The results in Table 2 showed that the total growing stock in the community was 
recorded at $1720 \mathrm{~m}^{3} \mathrm{ha}^{-1}$. Regarding the relationship between basal area $\left(\mathrm{m}^{2} \mathrm{ha}^{-1}\right)$ and growing stock $\left(\mathrm{m}^{3} \mathrm{ha}^{-1}\right)$, the results in Figure 2 showed a strong positive linear correlation with $\mathrm{R}^{2}$ value of 0.98 . The highly positive correlation of basal area and growing stock indicated that growing stock is the function of basal area (Nizami, 2012; Ahmad et al., 2014; Ahmad and Nizami, 2015; Saeed et al., 2019; Amir et al., 2018).

Table 1. Species composition and related attributes

\begin{tabular}{c|c|c|c|c|c|c|c}
\hline Species & D ha $^{-\mathbf{1}}$ & RD \% & BA ha $^{-1}$ & RB \% & F \% & RF \% & IVI \\
\hline Abies pindrow & 276 & 77.23 & 112.39 & 85.12 & 100.00 & 27.31 & 63.22 \\
Taxus baccata & 35 & 10.64 & 3.61 & 2.78 & 100 & 27.14 & 13.52 \\
Picea smithiana & 25 & 7.56 & 11.02 & 8.08 & 100 & 27.14 & 14.26 \\
Acer caesium & 3 & 0.65 & 0.53 & 0.33 & 28.57 & 5.83 & 2.27 \\
Juglans regia & 8 & 2.17 & 2.09 & 1.34 & 42.85 & 8.69 & 4.06 \\
Platanus orientalis & 4 & 1.11 & 2.51 & 1.66 & 21.42 & 4.04 & 2.27 \\
\hline Total & 350 & 100.00 & 132.15 & 100.00 & & 100.00 & 100.00 \\
\hline
\end{tabular}

$\mathrm{D}=$ Density, $\mathrm{RD}=$ Relative density, $\mathrm{BA}=$ Basal area, $\mathrm{RB}=$ Relative basal area, $\mathrm{F}=$ Frequency, $\mathrm{RF}=$ Relative frequency, IVI = Importance value index

Table 2. Volume and biomass carbon of upper storey vegetation

\begin{tabular}{c|c|c|c|c|c}
\hline Species & $\begin{array}{c}\text { Volume } \\
\mathbf{m}^{\mathbf{3}} \mathbf{h a}^{\mathbf{- 1}}\end{array}$ & $\begin{array}{c}\text { Stem biomass } \\
\mathbf{t ~ h a}^{\mathbf{1}}\end{array}$ & $\begin{array}{c}\text { Total tree } \\
\text { biomass t ha }^{\mathbf{1}}\end{array}$ & $\begin{array}{c}\text { Carbon stock } \\
\mathbf{t ~ h a}^{\mathbf{1}}\end{array}$ & Percentage \\
\hline Abies pindrow & 1425 & 528 & 800 & 400 & 82.64 \\
Taxus baccata & 54 & 20 & 30 & 15 & 3.08 \\
Picea smithiana & 164 & 60 & 94 & 47 & 9.66 \\
Acer caesium & 8 & 3 & 5 & 2 & 0.46 \\
Juglans regia & 31 & 11 & 18 & 9 & 1.83 \\
Platanus orientalis & 37 & 14 & 21 & 11 & 2.20 \\
\hline Total & 1720 & 636 & 967 & 484 & 100 \\
\hline
\end{tabular}

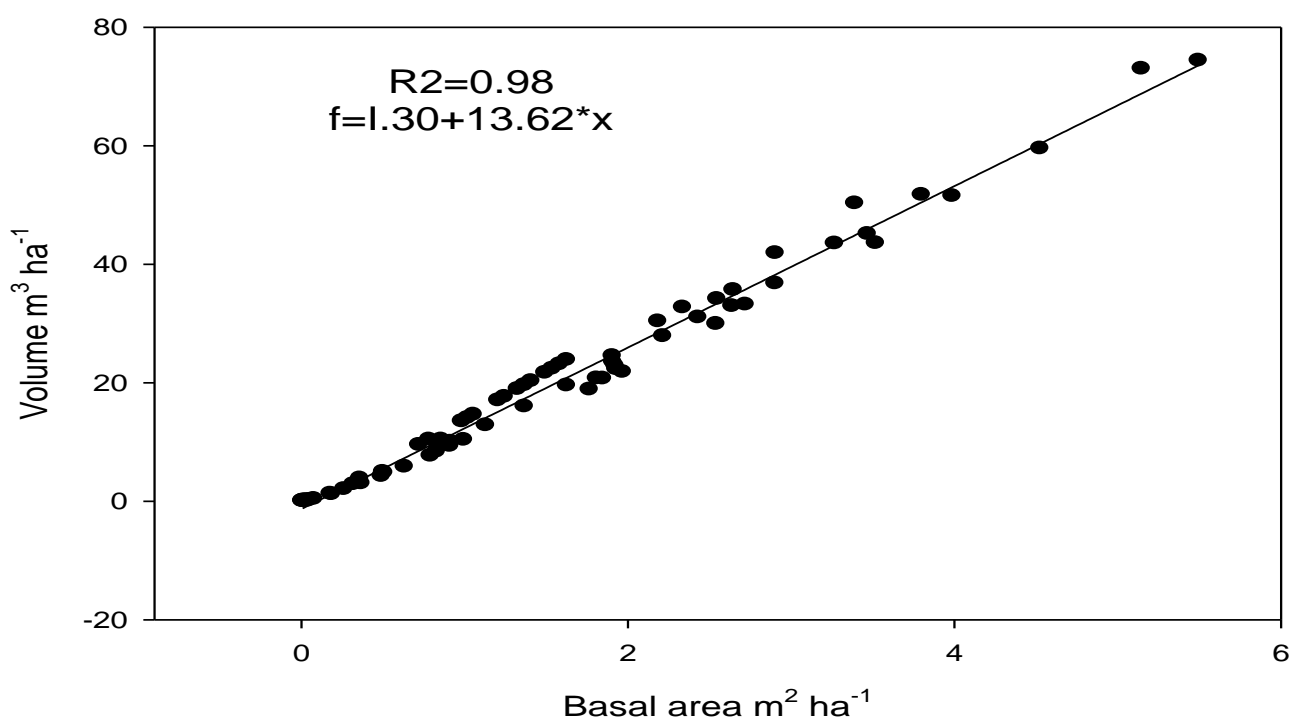

Figure 2. Relationship between volume $\left(\mathrm{m}^{3} h \mathrm{~h}^{-1}\right)$ and basal area $\mathrm{m}^{2} \mathrm{ha^{-1 }}$ 


\section{Biomass carbon}

The total tree biomass value varied between 5 and $800 \mathrm{t} \mathrm{ha}^{-1}$ (Table 2) with overall value of $967 \mathrm{t} \mathrm{ha}^{-1}$. The relationship of basal area $\left(\mathrm{m}^{2} \mathrm{ha}^{-1}\right)$ and biomass is presented in Figures 3 and 4 . The value of $\mathrm{R}^{2}$ suggested a very strong correlation between basal area and biomass. The basal area and biomass have a functional relationship and with increase in the basal area the biomass also increases (Nizami, 2012; Saeed et al., 2018). Under storey vegetation were mostly consist of grasses, forbs and shrubs. The average biomass of under storey vegetation was $2.87 \mathrm{t} \mathrm{ha}^{-1}$. The biomass carbon of the upper story vegetation was $484 \mathrm{t} \mathrm{ha}^{-1}$. In the total tree biomass carbon, the contribution of Abies pindrow was $82.64 \%$. In the under storey vegetation, the mean carbon stock was $1.43 \mathrm{t} \mathrm{ha}^{-1}$. Similarly, the carbon stock in litter, dead wood and cones was recorded as $12.02 \mathrm{t} \mathrm{ha}^{-1}$. The soil carbon varied from 52.13 to $81.78 \mathrm{t} \mathrm{ha}^{-1}$ (Table 3) with mean value of $70.74 \mathrm{t} \mathrm{ha}^{-1}$ (Table 4).

Table 3. Soil bulk density and soil organic carbon stock tons $h a^{-1}$

\begin{tabular}{c|c|c|c|c|c|c|c}
\hline Plot & $\begin{array}{c}\text { Bulk density } \\
(\mathbf{0 - 1 5} \mathbf{~ c m})\end{array}$ & $\begin{array}{c}\text { Bulk density } \\
(\mathbf{1 5 - 3 0} \mathbf{~ c m})\end{array}$ & $\begin{array}{c}\text { SOM } \\
\mathbf{\%}\end{array}$ & $\begin{array}{c}\text { SOM } \\
\mathbf{\%}\end{array}$ & $\begin{array}{c}\text { Total } \\
\text { SOM\% }\end{array}$ & $\begin{array}{c}\text { T otal } \\
\text { SOC\% }^{-}\end{array}$ & $\begin{array}{c}\text { SOC } \\
\text { tons ha-1 }^{-1}\end{array}$ \\
\hline 1 & 1.01 & 1.05 & 3.14 & 0.98 & 4.12 & 2.38 & 73.07 \\
2 & 1.009 & 1.04 & 3.39 & 1.19 & 4.58 & 2.65 & 80.46 \\
3 & 1.009 & 0.93 & 3.16 & 1.02 & 4.18 & 2.42 & 73.43 \\
4 & 0.99 & 1.03 & 2.84 & 1.02 & 3.86 & 2.23 & 66.52 \\
5 & 0.91 & 1 & 2.34 & 0.94 & 3.28 & 1.90 & 52.13 \\
6 & 0.99 & 0.89 & 2.54 & 0.78 & 3.32 & 1.92 & 57.21 \\
7 & 1 & 1.05 & 3.68 & 1.02 & 4.7 & 2.72 & 81.78 \\
8 & 0.99 & 0.95 & 3.78 & 0.94 & 4.72 & 2.73 & 81.34 \\
\hline Total & 7.908 & 7.94 & 24.87 & 7.89 & 32.76 & 18.95 & 565.94 \\
\hline
\end{tabular}

Table 4. Total carbon stock in forest ecosystem

\begin{tabular}{c|c|c}
\hline S. No & Carbon pools & Average carbon stock (tons ha-1) \\
\hline 1 & Upper storey vegetation carbon stock & 484 \\
2 & Under storey vegetation carbon stock & 1.43 \\
3 & Litter, dead wood and cones carbon stock & 12.02 \\
4 & Soil carbon stock & 70.74 \\
\hline \multicolumn{2}{l}{} & Total average carbon stock \\
\hline
\end{tabular}

Overall the results in Table 4 showed that the Abies pindrow community stored $568.63 \mathrm{t} \mathrm{ha}^{-1}$ carbon. The upper storey vegetation hold maximum carbon followed by soil, whereas the understory vegetation hold the minimum carbon. In compression the current carbon values in the biomass gives higher estimates from the reported values from Himalayan temperate regions (Sharma et al., 2010, 2011; Wani et al., 2014). This higher value might be the results of the presences of larger tree particularly of Abies pindrow. We found trees up to $150 \mathrm{~cm}$ in diameter that resulted in the maximum carbon value in the community. However, the soil carbon was found low from the reported value of Sharma et al. (2011) and Wani et al. (2014). This may be due to the 
management practices. The forest are managed forest and during management operations the dead wood are removed from the forest floor and upon the removal of the deadwood the forest floor have little deadwood stuff, resulting low soil carbon (Barbati et al., 2007).

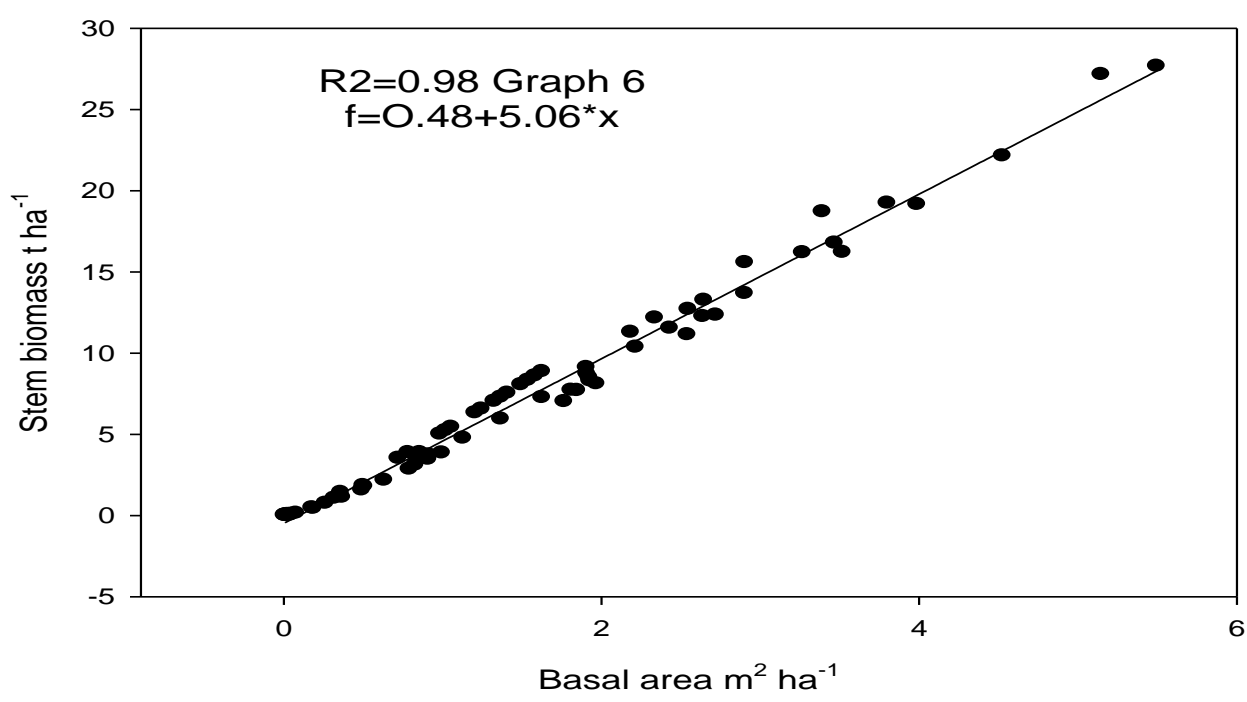

Figure 3. Relationship between stem biomass $\left(t h a^{-1}\right)$ and basal area $m^{2} h a^{-1}$

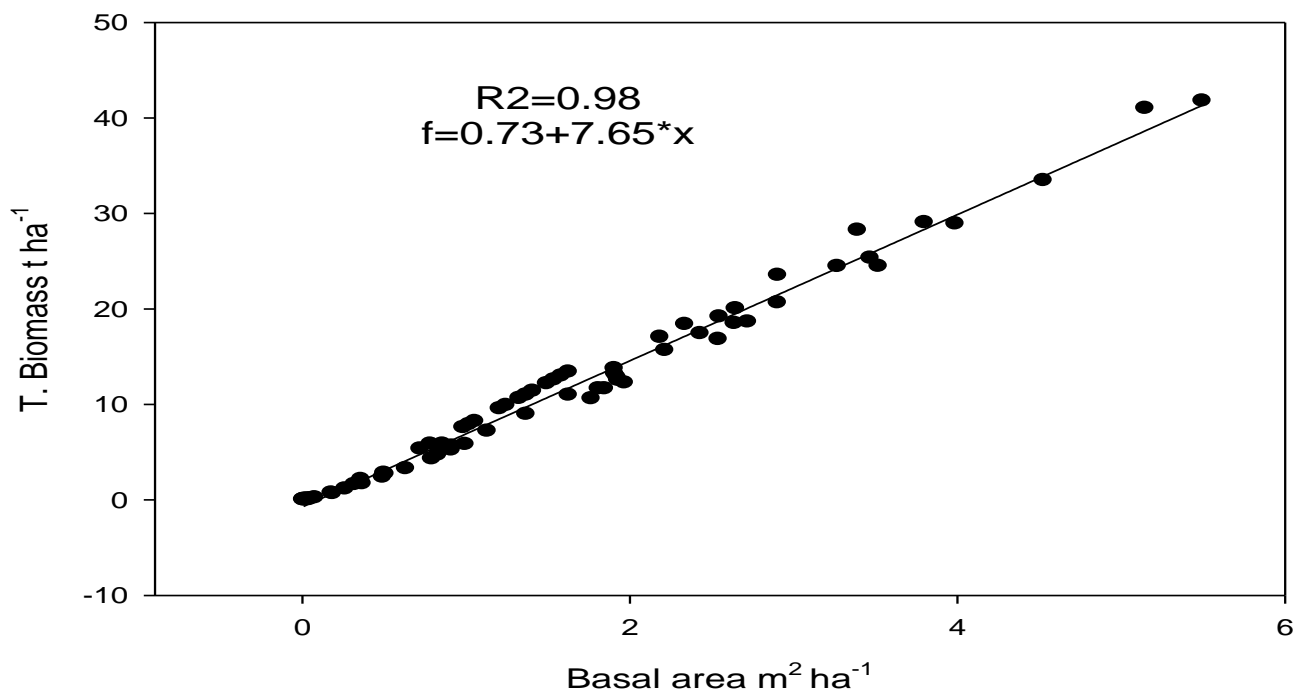

Figure 4. Relationship between stem biomass $\left(t h a^{-1}\right)$ and basal area $m^{2} h a^{-1}$

\section{Soil carbon stock}

Soil carbon in tons $\mathrm{ha}^{-1}$ was calculated from the relation of soil organic carbon (SOC $\%)$, Soil bulk density $\left(\mathrm{gm} / \mathrm{cm}^{3}\right)$ and thickness of horizon $(\mathrm{cm})$. Soil carbon was estimated by the use of different chemical solution like $\mathrm{M} \mathrm{K}_{2} \mathrm{Cr}_{2} \mathrm{O}_{7}$ and $\mathrm{H}_{2} \mathrm{SO}_{4}$. Composite soil samples were collected at $0-15$ and $15-30 \mathrm{~cm}$ depths from each inventory plot, using an auger. Soil carbon concentration ( $\mathrm{g} \mathrm{C} / \mathrm{g}$ of soil) was established using the Walkey-Black titration method. Data collection for desired objectives was 
recorded using standard procedures (FAO, 2005). The result of study showed that soil organic carbon stock decrease with increasing soil depth. The high value of organic carbon content showed that there is fast decomposition rate in forest litter in suitable environment. The soil organic carbon is affected due to different environmental factors geographic location along with slope. The average soil organic carbon was $70.75 \pm 11.26 \mathrm{t} \mathrm{ha}^{-1}$ with average soil bulk density $0.99 \pm 0.032$ was recorded.

\section{Soil PH}

Soil $\mathrm{pH}$ was measured by using soil $\mathrm{pH}$ meter (Mc Lean, 1982). The average $\mathrm{pH}$ was recorded $6.19 \pm 0.12$ the minimum soil $\mathrm{pH}$ was recorded 5.93 while maximum was 6.33 with coefficient variance. The result of the study shows that the soil was strongly acidic.

\section{Conclusion}

The presented finding in this study revealed that the Abies pindrow community having the greater carbon sequestration potential. However, the forest faces greater pressure in term of grazing, fuel wood collection and timber harvest. In this regard activities like Reduction in timber harvest, promotion of aforestation, reforestation, and the development of Hydropower should be imitated from the preservation and conservation of the forest.

\section{REFERENCES}

[1] Ahmad, A., Nizami, S. M. (2015): Carbon stocks of different land uses in the Kumrat valley, Hindu Kush Region of Pakistan. - Journal of Forest Research 26: 57-64.

[2] Ahmad, A., Nizami, S. M., Marwat, K. B., Muhammad, J. (2015): Annual accumulation of carbon in the coniferous forest of Dir Kohistan: An inventory based estimate. Pakistan Journal of Botany 47: 115-118.

[3] Ahmad, A., Liu, Q. I. J., Nizami, S. M., Mannan, A., Saeed, S. (2018): Carbon emission from deforestation, forest degradation and wood harvest in the temperate region of hindukush himalaya, pakistan between 1994 and 2016. - Land Use Policy 78: 781-790. DOI: https://doi.org/10.1016/j.landusepol.2018.07.009.

[4] Ahmad, A., Mirza, S. N., Nizami, S. M. (2014): Assessment of biomass and carbon stocks in Coniferous forest of Dir Kohistan, KPK. - Pakistan Journal of Agriculture Sciences 51: 335-340.

[5] Amir, M., Liu, X., Ahmad, A., Saeed, S., Mannan, A., Atif, M., M. (2018): Patterns of biomass and carbon allocation across chronosequence of chir pine (Pinus roxburghii) forest in Pakistan: inventory-based estimate. - Advances in Meteorology Article ID 3095891. https://doi.org/10.1155/2018/3095891.

[6] Barbati, A., Corona, P., Marchetti, M. (2007): A forest typology for monitoring sustainable forest management: the case of European forest types. - Plant Biosystems 141: 93-103.

[7] Böttcher, H., Kurz, W. A., Freibauer, A. (2008): Accounting of forest carbon sink and sources under a future climate protocol-factoring out past disturbance and management effects on age-class structure. - Environmental Science \& Policy 11: 669-686.

[8] Brown, S., Lugo A. E. (1982): The storage and production of organic matter in tropical forest and their role in global carbon cycle. - Biotropicia 14: 161-187. 
[9] Calfapietra, C., Barbati, A., Perugini, L., Ferrari, B., Guidolotti, G., Quatrini, A., Corona, P. (2015): Carbon mitigation potential of different forest ecosystems under climate change and various managements in Italy. - Ecosystem Health \& Sustainability 1: 1-9.

[10] Coulston, J. W., Wear, D. N., Vose, J. M. (2015): Complex forest dynamics indicate potential for slowing carbon accumulation in the southeastern United States. - Scientific Reports $\quad 5: \quad 8002 . \quad$ https://doi.org/10.1038/srep08002. https://www.nature.com/articles/srep08002\# supplementary- information.

[11] Curtis, J. T. (1959): The vegetation of Wisconsin: an ordination of plant communities: University of Wisconsin Press, Madison, WI.

[12] Espírito-Santo, F. D. B., Gloor, M., Keller, M., Malhi, Y., Saatchi, S., Nelson, B., Junior, R. C. O., Pereira, C., Lloyd, J., Frolking, S., Palace, M., Shimabukuro, Y. E., Duarte, V., Mendoza, A. M., López- González, G., Baker, T. R., Feldpausch, T. R., Brienen, R. J. W., Asner, G. P., Boyd, D. S., Phillips, O. L. (2014): Size And frequency of natural forest disturbances and the Amazon forest carbon balance. - Nature Communication 5: (3434).

[13] FAO. (2005). Global Forest Resource Assessment Rome, Italy.

[14] FAO (2015): Global Forest Resources Assessment. FAO Forestry Paper No. 1. - FAO, Rome.

[15] Haripriya, G. (2000): Estimates of biomass in Indian forests. - Biomass \& Bioenergy 19: 245-258.

[16] Hosonuma, N., Herold, M., de Sy, V., de Fries, R. S., Brockhaus, M., Verchot, L., Angelsen, A., Romijn, E. (2012): An assessment of deforestation and forest degradation drivers in developing countries. - Environmental Research Letters 7: 1-12.

[17] IPCC (2006): Intergovernmental Panel on Climate Change (IPCC) Guidelines for National Greenhouse Gas. - IPCC, Geneva.

[18] McLean, E. O. (1982). Soil pH and lime requirement. Methods of soil analysis. Part 2. Chemical and microbiological properties, (methodsofsoilan2), 199-224.

[19] Malhi, Y. B. T., Phillips, O. L., Almeida, S., Alvarez, E., Arroyo, L., Chave, J., CzimczikI, C. I., Fiore, A. D., Higuchi, N., Killeen, T. J., Laurance, S. G., Laurance, W. F., Lewis, S. L., Montoya, L. M., Lloyd, J. (2004): The above-groundcoarse wood productivity of 104 Neotropical forest plots. - Global Change Biology 101: 563-559.

[20] Mannan, A., Feng, Z., Ahmad, A., Liu, J., Saeed, S., Mukete, B. (2018): Carbon dynamics with land use change in Margallah Hills National Park, Islamabad (Pakistan) from 1990 to 2017. - Applied Ecology and Environmental Research 16(3): 3197-3214.

[21] Nizami, S. M. (2012): The inventory of the carbon stocks in sub tropical forests of Pakistan for reporting under Kyoto Protocol. - Journal of Forestry Research 23: 377-384.

[22] Pan, Y., Birdsey, R. A., Fang, J., Houghton, R., Kauppi, P. E., Kurz, W. A., Phillips, O. L., Shvidenko, A., Lewis, S. L., Canadell, J. G. et al. (2011): A large and persistent carbon sink in the world's forests. - Science 333: 988-993.

[23] Saeed, S., Sun, Y., Beckline, M., Chen, L., Lai, Z., Mannan, A., Ahmad, A., Shah, S., Amir, M., Ullah, T., Khan, A., Akbar, F. (2018): Altitudinal gradients and forest edge effect on soil organic carbon in chinese fir (Cunninghamia Lanceolata): a study from Southeastern China. - Applied Ecology and Environmental Research 17(1): 745-757.

[24] Saeed, S., Sun, Y., Beckline, M., Chen, L., Zhang, B., Ahmad, A., Mannan, A., Khan, A., Iqbal, A. (2019): Forest edge effect on biomass carbon along altitudinal gradients in Chinese Fir Cunninghamia lanceolata): a study from Southeastern China. - Carbon Management. DOI: 10.1080/17583004.2018.1537517.

[25] Sharma, C. M., Baduni, N. P., Gairola, S., Ghildiyal, S. K., Suyal, S. (2010): Treediversityand carbon stocks of some major forest types of Garhwal Himalaya, India. $\begin{array}{lllll}\text { Forest } & \text { Ecology } \quad \& \quad \text { Management 260: }\end{array}$ https://doi.org/10.1016/j.foreco.2010.09.014.

[26] Sharma, C. M., Gairola S., Baduni N. P., Ghildiyal S. K., Sarvesh, S. (2011): Variation in carbon stocks on different slope aspects in seven major types of temperate region of Garhwal Himalaya. - India Journal of Biosciences 36(4): 701-708. 
[27] Sharma, P., Rai, S. (2007): Carbon sequestration with land-use cover change in a Himalayan Watershed. - Geoderma 139: 371-378.

[28] Walkey, A., Black, I. A. (1934): An examination of the Degtjareff method for determining soil organic matter, and a proposed modification of the chromic acid titration method. - Soil Sciences 37: 29-38.

[29] Wani, A. A., Joshi, P., Singh, O., Bhat, J. (2014): Estimating soil carbon storage and mitigation under temperate coniferous forests in the southern region of Kashmir Himalayas. - Mitigation and Adaptation Strategies for Global Change 19: 1179-1194.

[30] Wani, A. A., Joshi, P. K., Singh, O., Shafi, S. (2016): Multi-temporal forest cover dynamics in Kashmir Himalayan region for assessing deforestation and forest degradation in the context of REDD+ policy. - Journal of Mitigation Science. 13: 1431-1441. https://doi.org/10.1007/ s11629-015-3545-3.

\section{APPENDIX}

Table A1. Geographic position and elevation of each plot

\begin{tabular}{c|c|c|c}
\hline Plot no & Elevation ft & Latitude & Longitude \\
\hline 1 & 8030 & $35^{\circ} 34^{\prime} .09^{\prime \prime}$ & $72^{\circ} 10^{\prime} .28^{\prime \prime}$ \\
2 & 8050 & $35^{\circ} 34^{\prime} .15^{\prime \prime}$ & $72^{\circ} 10^{\prime} .35^{\prime \prime}$ \\
3 & 8082 & $35^{\circ} 34^{\prime} .23^{\prime \prime}$ & $72^{\circ} 10^{\prime} .38^{\prime \prime}$ \\
4 & 8098 & $35^{\circ} 35^{\prime} .33^{\prime \prime}$ & $72^{\circ} 11^{\prime} .44^{\prime \prime}$ \\
5 & 8127 & $35^{\circ} 35^{\prime} .55^{\prime \prime}$ & $72^{\circ} 11^{\prime} .58^{\prime \prime}$ \\
6 & 8160 & $35^{\circ} 36^{\prime} .45^{\prime \prime}$ & $72^{\circ} 12^{\prime} .09^{\prime \prime}$ \\
7 & 8198 & $35^{\circ} 37^{\prime} .55^{\prime \prime}$ & $72^{\circ} 12^{\prime} .58^{\prime \prime}$ \\
8 & 8221 & $35^{\circ} 39^{\prime} .38^{\prime \prime}$ & $72^{\circ} 13^{\prime} .34^{\prime \prime}$ \\
9 & 8240 & $35^{\circ} 39^{\prime} .53^{\prime \prime}$ & $72^{\circ} 13^{\prime} .51^{\prime \prime}$ \\
10 & 8267 & $35^{\circ} 40^{\prime} .09^{\prime \prime}$ & $72^{\circ} 14^{\prime} .04^{\prime \prime}$ \\
11 & 8289 & $35^{\circ} 40^{\prime} .50^{\prime \prime}$ & $72^{\circ} 14^{\prime} .49^{\prime \prime}$ \\
12 & 8308 & $35^{\circ} 41^{\prime} .44^{\prime \prime}$ & $72^{\circ} 15^{\prime} .22^{\prime \prime}$ \\
13 & 8345 & $35^{\circ} 42.51^{\prime \prime}$ & $72^{\circ} 15^{\prime} .51^{\prime \prime}$ \\
14 & 8431 & $35^{\circ} 43^{\prime} .15^{\prime \prime}$ & $72^{\circ} 16^{\prime} .35^{\prime \prime}$ \\
\hline
\end{tabular}

Table A2. Soil bulk density and soil organic carbon stock tons $\mathrm{ha}^{-1}$

\begin{tabular}{c|c|c|c|c|c|c|c}
\hline Plot & $\begin{array}{c}\text { Bulk density } \\
(\mathbf{0 - 1 5} \mathbf{~ c m})\end{array}$ & $\begin{array}{c}\text { Bulk density } \\
(\mathbf{1 5 - 3 0} \mathbf{~ c m})\end{array}$ & SOM\% & SOM\% & $\begin{array}{c}\text { Total } \\
\text { SOM\% }\end{array}$ & $\begin{array}{c}\text { T } \\
\text { SOC\% }\end{array}$ & $\begin{array}{c}\text { SOC } \\
\text { tons ha }^{-1}\end{array}$ \\
\hline 1 & 1.01923 & 1.05769 & 3.14 & 0.98 & 4.12 & 2.38 & 73.0724 \\
2 & 1.009615 & 1.04808 & 3.39 & 1.19 & 4.58 & 2.65 & 80.4647 \\
3 & 1.009615 & 0.93269 & 3.16 & 1.02 & 4.18 & 2.42 & 73.4372 \\
4 & 0.99038 & 1.03846 & 2.84 & 1.02 & 3.86 & 2.23 & 66.5235 \\
5 & 0.91346 & 1 & 2.34 & 0.94 & 3.28 & 1.90 & 52.1372 \\
6 & 0.99038 & 0.89423 & 2.54 & 0.78 & 3.32 & 1.92 & 57.2171 \\
7 & 1 & 3.05769 & 1.02 & 4.7 & 2.72 & 81.7865 \\
8 & 0.95192 & 3.78 & 0.94 & 4.72 & 2.73 & 81.3448 \\
Mean & 0.99038 & 0.99759 & 3.10 & 0.98 & 4.095 & 2.37 & 70.7479 \\
SD & 0.03291 & 0.06372 & 0.51 & 0.11 & 0.5757 & 0.33 & 11.2661 \\
Std error & 0.01163 & 0.02253 & 0.18 & 0.04 & 0.2035 & 0.11 & 3.98318 \\
Variance & 0.00108 & 0.00406 & 0.26 & 0.01 & 0.3314 & 0.11 & 126.925 \\
CV \% & 3.32292 & 6.3883 & 16.5 & 11.6 & 14.057 & 14.05 & 15.9243 \\
\hline
\end{tabular}

